International Journal of Business Management and Economic Review

Vol. 5, No. 01; 2022

ISSN: 2581-4664

\title{
THE EFFECT OF ORGANIZATIONAL COMMITMENT, SERVANT LEADERSHIP, AND EMPOWERMENT ON EMPLOYEE PERFORMANCE WITH \\ ORGANIZATIONAL CITIZENSHIP BEHAVIOR AS A MEDIATION AT REGIONAL GENERAL HOSPITAL dr. ZAINOEL ABIDIN BANDA ACEH
}

\author{
* Iswahyudi, Muslim A Djalil and Sofyan Idris \\ Management Department, Universitas Syiah Kuala, Indonesia \\ http://doi.org/10.35409/IJBMER.2022.3357
}

\begin{abstract}
This study aims to examine the model of the influence of organizational commitment, servant leadership, and empowerment on employee performance, by utilizing organizational citizenship behavior (OC behavior) as a mediator. The study was conducted at the dr. zainoel Abidin (RSUDZA) in the city of Banda Aceh. The population is all medical and non-medical personnel, totaling 1029 people. Sampling using accidental sampling technique, to obtain as many as 288 people. The variable measurement scale used is the Likert scale. The research model was analyzed using Structural Equation Modeling (SEM) using Amos software. The results of direct hypothesis testing prove that commitment does not affect OC behavior, Servant leadership and empowerment affect OC behavior, commitment and empowerment have no effect on performance, servant leadership and OC behavior affect performance. The indirect hypothesis testing proves that OC behavior does not mediate the role of commitment on performance, and OC behavior partially mediates the role of servant leadership and empowerment on performance. This explains that the RSUDZA performance improvement model is a function of strengthening servant leadership, increasing empowerment, and strengthening OC behavior. This test result model can be an academic basis for future researchers in developing further research. For RSUDZA, this model can be used for making advanced management regulations to improve its performance.
\end{abstract}

Keyword: Organizational Commitment, Servant Leadership, Empowerment, Organizational Citizenship Behavior, Employee Performance.

\section{INTRODUCTION}

Regional General Hospital (RSUD) is a health service institution owned by the Regional Government, RSUD is the main referral health facility for people who want to obtain health services both for treatment and for health recovery, therefore, hospitals are required to be able to provide comprehensive health services. for each patient. The density of existing human resources in hospitals consisting of various professions is an important thing in supporting the development of hospitals and becomes a benchmark in assessing the development of hospital service quality.

Regional General Hospital dr. Zainoel Abidin (RSUDZA) Banda Aceh is one of the public institutions that is currently undergoing a revitalization of hospital service performance by the Aceh Government. This revitalization was carried out because of complaints from patients and their families which so far still often occur, especially related to hospital services. The Regional 


\section{International Journal of Business Management and Economic Review}

Vol. 5, No. 01; 2022

ISSN: 2581-4664

Secretary asked the head of the polyclinic to maximize their authority to manage the room so that patients and their families feel well served. The goal is to provide maximum hospital services to patients. The poor quality of this service cannot be separated from the poor performance of the Banda Aceh Regional Hospital's employees (https://bpba.acehprov.go.id/,17/05/2021). Law Number 23 of 2014 concerning Regional Government mandates the efforts of local governments to meet the needs of the community as a form of public service so that the community can provide feedback on public services provided by local governments.

There are still reports from the public who complain about the services of nurses and doctors which are considered less than the maximum received by the Indonesian Ombudsman for Aceh Representatives (https:// Ombudsman.go.id, Selasa, 13/03/2018). In addition, one of the Advocacy Foundations urged the Acting Governor of Aceh to remove the Director of RSUDZA regarding the neglect of patients by doctors in the emergency room of the hospital. The patient who had a high fever had fallen to the floor from the wheelchair in front of the doctor's desk, because his condition was getting weaker, but had not yet received service from the nurses or doctors (rri.co.id, Senin 10/12/2018). The Aceh Party faction in the DPRA also highlighted RSUZA's services related to the community who complained because many medics did not show an attitude as community servants, and there was often no information obtained regarding family medical records (Serambinews.com, 2018). The contribution of employees is needed as a form of achievement of the performance of the institution. This behavior to contribute within the scope of the organization is often referred to as Organizational Citizenship Behavior (OC behavior) (Purba \& Seniati, 2004).

Looking at the performance phenomenon, it shows that the OC behavior owned by employees at RSUDZA is still inadequate. This is indicated by the number of complaints received by the community regarding the services received by them. Many things in the future must be addressed by the management of RSUDZA to improve the performance of its employees and the OC Behavior of the employees themselves. Some of the things indicated are related to commitment, servant leadership, and employee empowerment. This was done because the results of the initial survey showed that commitment, servant leadership, and empowerment of RSUDZA employees were still not good whereas the survey results revealed an average commitment score of 3.37. While servant leadership is worth 3.30 and employee empowerment is worth 3.05 where on the Likert scale this value shows in the poor category.

Moving on from the phenomena mentioned above, this study aims to examine the model of the Effect of Commitment, Servant Leadership, and Empowerment on Performance with OC Behavior as Mediator at RSUDZA. This study focuses on OC Behavior and the performance of employees who are not optimal in organizational performance to achieve organizational goals.

\section{LITERATURE STUDY}

\section{Employee Performance}

Every employee is required to make a positive contribution (Gibson, Ivancevic, \& Konopaske, 2012). (Yukl, 2010) use the term proficiency which has a broader meaning. Employee performance, which is in this research is often mentioned as performance, is not just information for promotion or salary determination for the organization, but how the organization can motivate employees and develop a plan to improve performance slumps can be avoided. According to (Idowu, 2017), his research stated that the performance appraisal 


\section{International Journal of Business Management and Economic Review}

Vol. 5, No. 01; 2022

ISSN: 2581-4664

system was quite effective in offering a comprehensive analysis of employee performance. In addition, another factor that affects employee performance is OC Behavior. Apart from OC Behavior, (Wirawan, 2012) and (Edison, Riyanti, \& Yustiana, 2016) mentions that organizational commitment, servant leadership, and empowerment are also factors that can influence employee performance.

\section{Organizational Citizenship Behavior}

(Organ, 2015) and (Huang, Wang, \& Xie, 2014) states, OC Behavior is a term used as behavior that benefits the organization or intends to benefit the organization that directly leads to the role of expectations. OC Behavior is an extra-role behavior that can benefit the organization. This behavior is a behavior that is voluntary in nature. OC Behavior can provide the benefits of increasing the productivity of co-workers, increasing manager productivity, saving management resources and the organization as a whole, helping to save energy resources that are necessary for maintaining group functions, effectively coordinating group activities, increasing the organization's ability to attract and retain the best employees, improve organizational performance stability, improve the organization's ability to adapt to environmental changes. According to (Cahyono, 2015) and (Titisari, 2014) mentions that OC Behavior is influenced by two dimensions, namely internal factors consisting of job satisfaction, organizational commitment, personality, employee morale, motivation, organizational climate, while the dimensions of external factors are leadership style, trust in leaders, and organizational culture.

\section{Organizational Commitment}

According to (Greenberg \& Baron, 2007), in (Chairy, 2011), Employees who have high organizational commitment are more stable and more productive. (Mowday, Porter, \& Steers, 1982), in (Chairy, 2011) suggests the characteristics of organizational commitment, namely: (1) a strong belief in and acceptance of the goals and values of the organization; (2) readiness to work hard; and (3) a strong desire to stay in the organization. (Daft \& Marcic, 2008) define organizational commitment is as loyalty and significant involvement in the organization. In addition, it is also stated that Organizational commitment affects performance in an organization. Employee satisfaction on material compensation and social compensation has a significant influence on employee loyalty to the organization. Organizational commitment is associated with increased results. For individuals or employees with high organizational commitment, achieving organizational goals is important. Organizational commitment is often mentioned as commitment in this research.

\section{Servant Leadership}

Servant leadership is a leadership style characterized by an emphasis on opportunities to help followers grow and develop (Robbins \& Judge, 2017). Servant leadership is leadership that starts from sincere feelings that arise from within the heart that wants to serve (Neuschel, 2008). (Northouse, 2013) also added that servant leadership is a leader who serves their people or their subordinates and not vice versa. Leaders at the top level give orders to middle-level management, middle-level leaders give orders to their employees, and ultimately employees at lower levels serve their customers. (Northouse, 2013) added that servant leadership is a leader who serves their people or their subordinates and not vice versa. Leaders at the top level give orders to middle-level 
Vol. 5, No. 01; 2022

ISSN: 2581-4664

management, middle-level leaders give orders to their employees, and ultimately employees at lower levels serve their customers. He also identified 10 characteristics of servant leadership namely listening, empathy, healing, caring, persuasion, conceptualization, forecasting, duty to care, commitment to people growth, and community building.

\section{Empowerment}

Organizations must be able to adapt to changes and developments that occur outside the organization to survive, even more so in today's times, where changes and developments in technology, knowledge, economy, and the environment occur rapidly, so organizations need employees who are more creative, full of energy, initiative, and able to take on greater responsibilities. Empowerment is increasingly considered important by organizations because employees are no longer prepared only to accept a command and control system (Sinurat, 2004). By empowering the organization, it is possible to maximize the utilization of the capabilities and knowledge of its employees, to increase employee productivity, involvement, and sense of responsibility (Hasibuan, 2016);(Rahayu \& Rozak, 2021). According to (Daraei, Maymand, \& Ekhtari, 2014), Empowerment is often defined as an act of providing opportunities to make job decisions by expanding their authority in decision making.

\section{Research Framework}

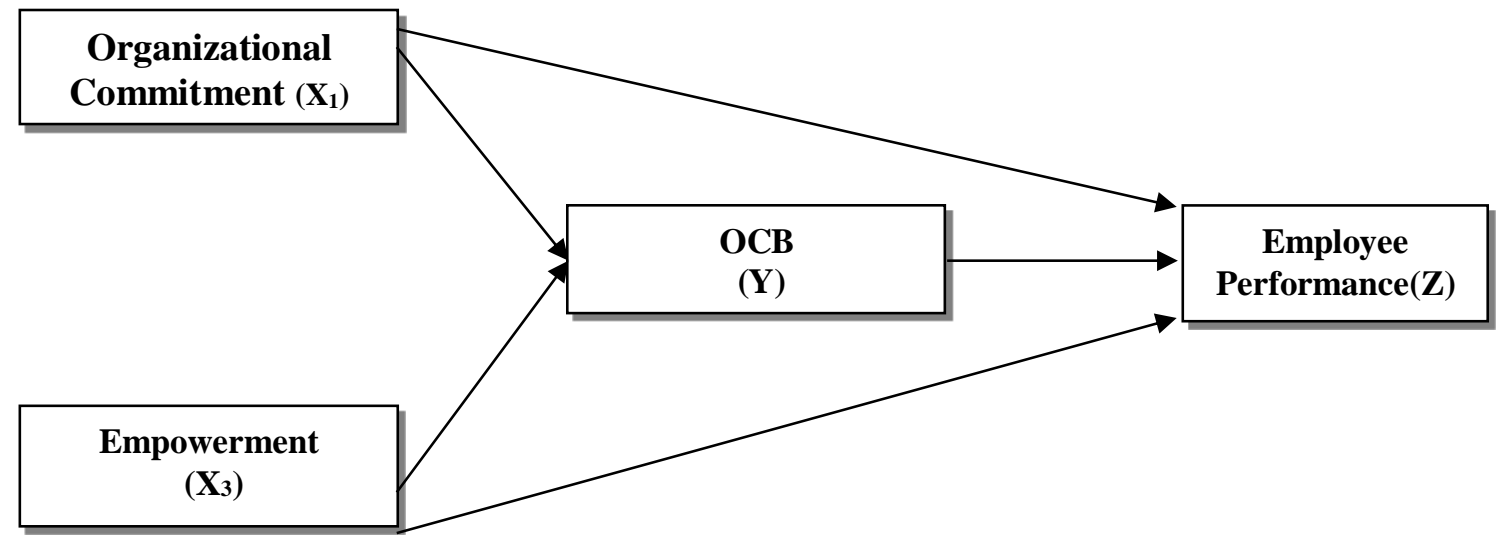

Figure 1. Research Framework

\section{Hypothesis}

H1: Commitment Affects OC Behavior

H2: Servant Leadership affects OC Behavior

H3: Empowerment affects OC Behavior

H4: Commitment Affects Performance.

H5: Servant Leadership affects Performance.

H6: Empowerment affects performance.

H7: OC Behavior affects performance

H8: OC Behavior mediates the effect of Commitment on Performance. 
International Journal of Business Management and Economic Review

Vol. 5, No. 01; 2022

ISSN: 2581-4664

H9: OC Behavior mediates the effect of Servant Leadership on Performance.

H10: OC Behavior mediates the effect of Empowerment on Performance.

\section{RESEARCH METHOD}

The study explains the effect of organizational commitment, servant leadership, and trust on employee performance with OC Behavior as a Mediator at RSUDZA. Data were collected through distributing questionnaires to medical and non-medical employees. Secondary data collection in this study is in the form of document recording, among others, by collecting data in the form of documentation sourced from research subjects.

The population of this study was all medical and non-medical employees at RSUDZA. The details of the data for civil servants and honorary workers who work can be seen below.

Table 1. Population

\begin{tabular}{|l|l|l|}
\hline No & Work unit & Amount \\
\hline \multirow{4}{*}{1} & Medical personnel & \\
\cline { 2 - 3 } & - Medical specialist & 177 \\
\cline { 2 - 3 } & - Dentist & 6 \\
\cline { 2 - 3 } & - General practitioners & 32 \\
\hline 2 & Non-Nurse Paramedic Personnel & 246 \\
\hline 3 & Nursing Paramedics & 568 \\
\hline \multicolumn{2}{|l|}{ Total Employees } & 1029 \\
\hline
\end{tabular}

Source: RSUDZA (2020)

This study used an accidental sampling technique which is a sampling method by chance. The number of samples was determined using the Slovin formula and resulted in as many as 288 respondents. In this study, the researcher builds a construct for each of the variables studied based on previous theories, and the provisions that bind performance measurement, namely:

1. Employee performance used indicators disclosed by (Prawirosentono, 2010) namely quantity, quality, time, cost, service orientation, integrity, commitment, discipline, cooperation, leadership.

2. OC Behavior used indicators disclosed by (Organ, 2015), namely obeying the rules, awareness, helping face difficulties, helping people around, attention, playing an active role in improvement, not complaining, maintaining relationships, reminding colleagues in preventing problems.

3. Organizational commitment used indicators disclosed by (Coryanata, 2014) namely a sense of belonging to the organization, a sense of attachment to the organization, the meaning of the organization personally, will not leave the organization, proud of the organization, loyalty.

4. Servant leadership used indicators disclosed by (Poli, 2019) i.e. listening, empathy, healing, caring, persuasion, conceptualization, forecasting, duty to care for, commitment to growth, community building

5. Empowerment used indicators disclosed by (Daraei et al., 2014) i.e. the work done is important, work activities have meaning, cares about what is done, determines for themselves how the work is done, has the autonomy to make decisions in the work process, has the 


\section{International Journal of Business Management and Economic Review}

Vol. 5, No. 01; 2022

ISSN: 2581-4664

opportunity to choose how to do work, has a great impact on events in the organization, has control on events in the organization, the work done the results achieved by the organization.

Direct hypothesis testing using Structural Equation Modeling (SEM) analysis tools through the use of Amos software (Hair, Hult, Ringle, \& Sarstedt, 2016). Furthermore, indirect hypothesis testing (mediation) was carried out using the model (Baron \& Kenny, 1986).

\section{RESULTS}

\section{Direct Effect}

The structural model is figured as follows.

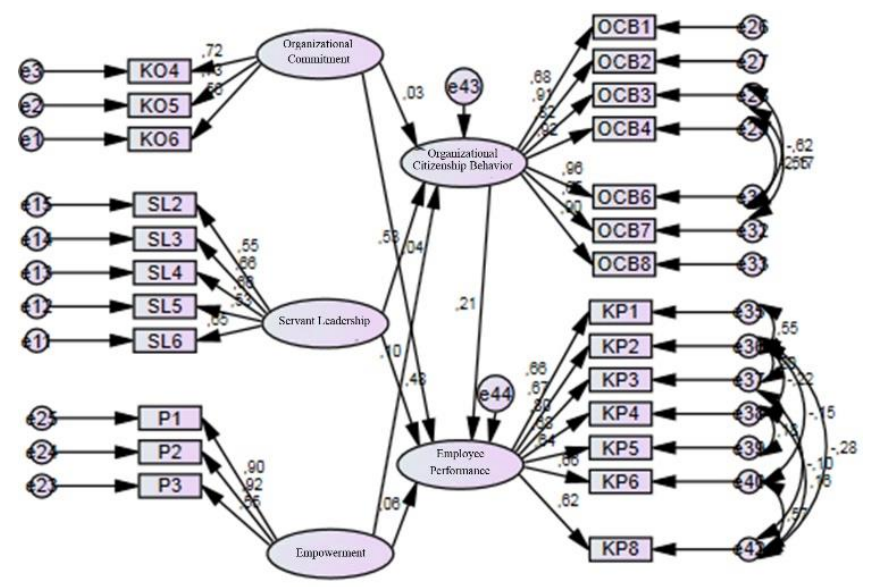

Figure 2. SEM Test Results

The results of hypothesis testing through a full model after fulfilling the SEM assumptions are clearly presented below.

Table 2. Test Results

\begin{tabular}{|c|c|c|c|c|c|c|}
\hline & & Estimate & S.E. & C.R. & $\mathrm{P}$ & $\begin{array}{l}\text { R- } \\
\text { Square }\end{array}$ \\
\hline OC Behavior & <--- Commitment & 0.034 & 0.072 & 0.692 & 0.489 & \multirow[b]{2}{*}{0.295} \\
\hline OC Behavior & $<---\quad$ Servant Leadership & 0.533 & 0.076 & 7.826 & 0.000 & \\
\hline OC Behavior & $<---$ Empowerment & 0.100 & 0.043 & 2.230 & 0.026 & \multirow{5}{*}{0.386} \\
\hline Performance & <--- Commitment & 0.038 & 0.055 & 0.600 & 0.549 & \\
\hline Performance & <--- Servant Leadership & 0.478 & 0.058 & 5.439 & 0.000 & \\
\hline Performance & $<---$ Empowerment & 0.062 & 0.048 & 1.069 & 0.285 & \\
\hline Performance & $<---$ OC Behavior & 0.209 & 0.035 & 3.526 & 0.000 & \\
\hline
\end{tabular}

Source: Primary Data, 2021 (processed)

The SEM analysis also resulted in the formulation of the statistical equation as follows:

OC Behavior

$=0.034$ Organizational Commitment +0.533 Servant Leadership +0.100

Empowerment 
International Journal of Business Management and Economic Review

Vol. 5, No. 01; 2022

ISSN: 2581-4664

Employee Performance $=0.038$ Organizational Commitment +0.478 Servant Leadership +0.062 Empowerment + 0.209 OC Behavior

The results of the direct influence test in the table above are explained that:

1. In Table 2, the $\mathrm{R}$ square value for the role of Commitment and Servant Leadership on OC Behavior is 0.295 . This figure shows that together the variables of Commitment and Servant Leadership can explain the OC Behavior variable of $29.5 \%$, while the remaining $71.5 \%$ is explained by other variables that are not in this study.

2. The value of $\mathrm{R}$ square for the effect of Commitment, Servant Leadership, and OC Behavior on Performance is 0.386. This figure shows that together the variables of Commitment, Servant Leadership, Empowerment, and OC Behavior can explain the Performance variable of $38.6 \%$, while the remaining $61.4 \%$ is explained by other variables that are not in this study.

3. Testing Commitment on OC Behavior produces a CR of 0.692 and $\mathrm{p}$ of 0.489 . The figure concludes that Commitment does not affect increasing OC Behavior.

4. Testing Servant Leadership on OC Behavior produces a CR of 7.826 and $p$ of 0.000 . The figure concludes that Servant Leadership affects increasing OC Behavior. The coefficient of the role of Servant Leadership in OC Behavior is 0.533 or $53.3 \%$. This reveals that the higher the level of Servant Leadership, the higher the OC Behavior of employees.

5. Empowerment testing on OC Behavior produces a CR of 2.230 and $\mathrm{p}$ of 0.026 . The figure concludes that Empowerment affects increasing OC Behavior. The coefficient of the role of Empowerment in OC Behavior is 0.100 or $10.0 \%$. This explains that the higher the level of empowerment, the higher the OC Behavior of employees.

6. Testing Commitment on Performance produces a CR of 0.600 and $p$ of 0.549 . The figure concludes that Commitment does not affect Performance. The coefficient of the role of Commitment on Performance is 0.223 or $22.3 \%$.

7. Testing Servant Leadership on Performance resulted in a CR of 5,439 and p of 0.000. This figure concludes that Servant Leadership influences increasing performance. The coefficient of the role of Servant Leadership on Performance is 0.478 or $47.8 \%$. This illustrates that the higher the level of Servant Leadership will further improve performance.

8. Empowerment Testing on Performance resulted in a CR of 1.069 and $\mathrm{p}$ of 0.285 . The figure concludes that Empowerment does not affect improving Performance.

9. OC Behavior testing on performance resulted in a CR of 3,526 and p of 0.000. The figure concludes that OC Behavior affects Performance. The coefficient of the role of OC Behavior on Performance is 0.209 or $20.9 \%$. This reveals that the higher the OC Behavior will have a direct effect on improving performance.

The results of testing the indirect hypothesis are as shown in the following explanation:

1. Testing Commitment on Performance through OC Behavior

The results of the mediating effect of the variable Commitment on Performance are presented as follows: 
Vol. 5, No. 01; 2022

ISSN: 2581-4664

\section{Employee \\ Performance}

Figure. 3 Testing the Mediating Effect of Hypothesis 8

Sobel test resulted in a statistical test value of 0.470 and significant at $=0.637$. Thus, OC Behavior does not act as a mediating variable between Commitment and Performance.

Based on Figure 3, the results of the Sobel scores can be seen in Figure 4 as follows:

\begin{tabular}{|c|c|c|c|c|}
\hline Input: & & Test statistic: & Std. Error: & $p$-value: \\
\hline a 0.034 & Sobel test: & 0.47075255 & 0.01509498 & 0.63781745 \\
\hline$b 0.209$ & Aroian test: & 0.46432663 & 0.01530388 & 0.64241375 \\
\hline$s_{\mathrm{a}} 0.072$ & Goodman test: & 0.47745285 & 0.01488314 & 0.63303969 \\
\hline$s_{\mathrm{b}} 0.035$ & Reset all & \multicolumn{3}{|c|}{ Calculate } \\
\hline
\end{tabular}

Figure 4. Sobel Test Results of Hypothesis 8

2. Testing Servant Leadership on Performance through OC Behavior

The results of the mediating effect of the Servant Leadership variable on OC Behavior are presented as follows:

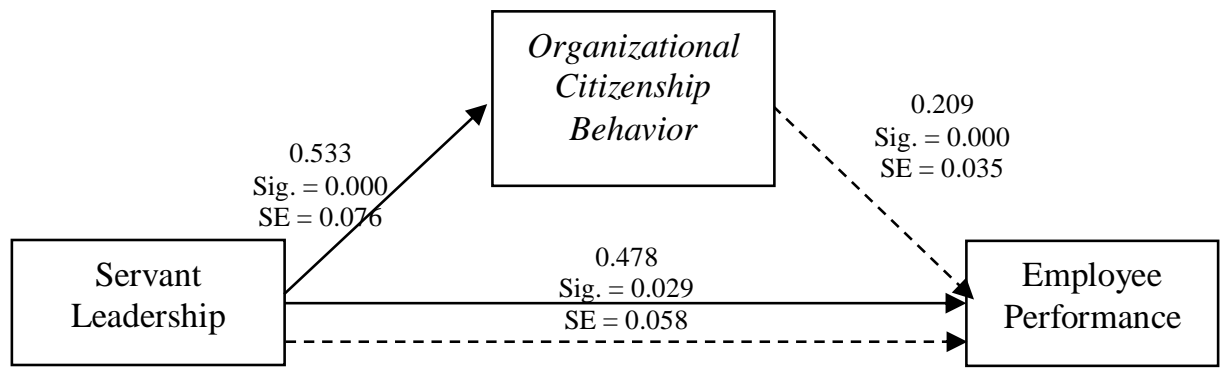

Figure 5. Testing the Mediating Effect of Hypothesis 9

Sobel test resulted in a statistical test value of 4.546 and significant at $=0.000$. Thus, OC Behavior acts as a mediator between Servant Leadership and Performance. Thus, because OC Behavior affects and acts as a mediating variable, Servant Leadership affects performance, the role of OC Behavior in mediating the relationship between Servant Leadership and performance is partially mediating. Mediation partially shows that OC Behavior is not able to perfectly mediate the effect of Servant Leadership on Performance where there are still other variables not examined that can mediate the effect of Servant Leadership on Performance.

Based on Figure 5, the results of the Sobel value can be seen in Figure 6 as follows: 


\section{International Journal of Business Management and Economic Review}

Vol. 5, No. 01; 2022

ISSN: 2581-4664

\begin{tabular}{|c|c|c|c|c|}
\hline Input: & & Test statistic: & Std. Error: & $p$-value: \\
\hline a 0.533 & Sobel test: & 4.54658728 & 0.02450123 & 0.00000545 \\
\hline$b \longdiv { 0 . 2 0 9 }$ & Aroian test: & 4.5200275 & 0.0246452 & 0.00000618 \\
\hline$s_{a} 0.076$ & Goodman test: & 4.57362082 & 0.02435641 & 0.00000479 \\
\hline$s_{b} 0.035$ & Reset all & & Calculate & \\
\hline
\end{tabular}

Figure 6. Sobel Test Results of Hypothesis 9

3. Empowerment Testing on Performance through OC Behavior

The results of the mediating effect of the Empowerment variable on OC Behavior are presented as follows:

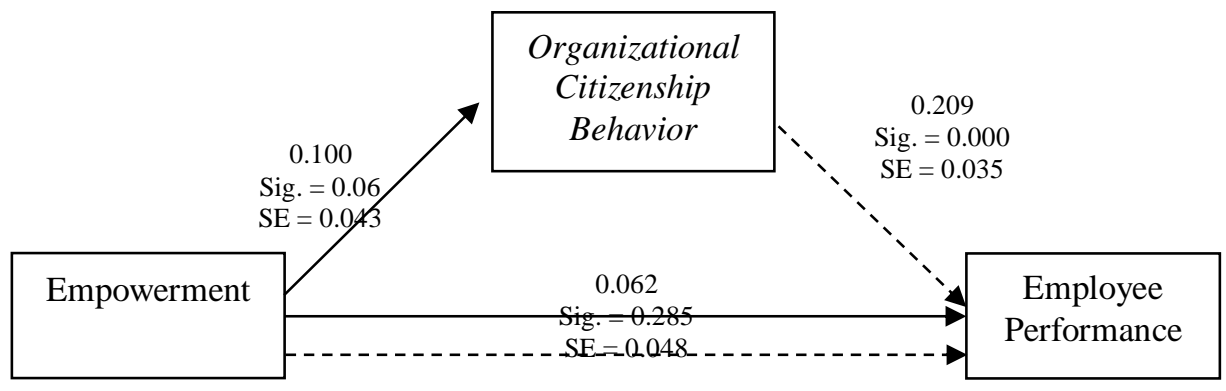

Figure 7. Testing the Mediating Effect of Hypothesis 10

The Sobel test resulted in a statistical test value of 2.167 and was significant at $=0.030$. Thus, OC Behavior acts as a mediator between Empowerment and Performance. So, because OC Behavior affects and acts as a mediating variable, Empowerment does not affect Performance, then OC Behavior's role in mediating the relationship between Empowerment and Performance is fully mediating. Mediation in full shows that OC Behavior can perfectly mediate the influence of Servant Leadership on Performance.

Based on Figure 7, the results of the Sobel scores can be seen in Figure 8 as follows:

\begin{tabular}{|c|c|c|c|c|}
\hline Input: & & Test statistic: & Std. Error: & $p$-value: \\
\hline a 0.100 & Sobel test: & 2.16704067 & 0.00964449 & 0.03023175 \\
\hline$b 0.209$ & Aroian test: & 2.14112829 & 0.00976121 & 0.03226369 \\
\hline$s_{a} 0.043$ & Goodman test: & 2.19391719 & 0.00952634 & 0.02824136 \\
\hline$s_{\mathrm{b}} 0.035$ & Reset all & & Calculate & \\
\hline
\end{tabular}

Figure 8. Sobel Test Results of Hypothesis 10

\section{CONCLUSION}

The results of the study at RSUDZA show that the results of hypothesis testing directly prove commitment does not affect OC Behavior, Servant leadership and empowerment affect OC 


\section{International Journal of Business Management and Economic Review}

Vol. 5, No. 01; 2022

ISSN: 2581-4664

Behavior, commitment and empowerment do not affect performance, servant leadership and OC Behavior affect performance. Indirect hypothesis testing proves that OC Behavior does not mediate the effect of commitment on performance, and OC Behavior partially mediates the influence of servant leadership and empowerment on performance. This explains that the RSUDZA performance improvement model is a function of strengthening servant leadership, increasing empowerment, and strengthening OC Behavior. This test result model can be an academic basis for future researchers in developing further research. For RSUDZA, this model can be used for making advanced management regulations to improve its performance. The limitation of this study is the number of variables and research subject.

\section{REFERENCES}

Baron, R. M., \& Kenny, D. A. (1986). The moderator-mediator variable distinction in social psychological research: Conceptual, strategic, and statistical considerations. Journal of Personality and Social Psychology, 51(6), 1173.

Chairy. (2011). Pengaruh Karakteristik Entrepreneurial, Jenis Etnis, Jenis Kelamin dan Profesi Orang Tua Terhadap Intensi Berwirausaha Mahasiswa. Jurnal Manajemen Bisnis, 1(2), 245259.

Coryanata, I. (2014). Pelimpahan Wewenang dan Komitmen organisasi Dalam Hubungan Antara Partisipasi Penyusunan Anggaran dan Kinerja Managerial. Makalah Simposium Nasional Akuntansi (SNA) VII.

Daft, R. L., \& Marcic, D. (2008). Understanding management (10th ed.). Kentucky: South Western Educational Publishing.

Daraei, M. R., Maymand, M. M., \& Ekhtari, H. (2014). Providing A Conceptual Model For Surveying The Impact Of Employee Empowerment On Organizatioal Citizenship Behavior (OCB) In Alborz Insurance Company. Journal of Current Research in Science, 2(6), 794800.

Edison, E., Riyanti, A., \& Yustiana, D. (2016). Budaya Organisasi Dalam Aspek Peningkatan Kinerja Karyawan (Studi Kasus Di Hotel Perdana Wisata, Bandung). Tourism Scientific Journal, 1(2), 134-151. https://doi.org/http://dx.doi.org/10.32659/tsj.v1i2.8

Gibson, J., Ivancevic, J., \& Konopaske, R. (2012). Organizations: Behavior, Structure, Processes (14th ed.). New York: Mc Graw Hill.

Greenberg, J., \& Baron, R. A. (2007). Behavior In Organizations (9th ed.). United States: Prentice Hall.

Hair, J. F., Hult, G. T. M., Ringle, C., \& Sarstedt, M. (2016). A Primer on Partial Least Squares Structural Equation Modeling (PLS-SEM) (2nd ed.). Thousand Oaks: Sage Publications, Inc.

Hasibuan, M. S. (2016). Buku Manajemen Sumber Daya Manusia (Revisi). Jakarta: Bumi Aksara. Huang, J., Wang, L., \& Xie, J. (2014). Leader-Member Exchange and Organizational Citizenship Behavior: the Roles of Identification with Leader and Leader's Reputation. Social Behavior and Personality An International Journal, 42(10), 1699-1712. https://doi.org/https://doi.org/10.2224/sbp.2014.42.10.1699

Idowu, A. O. (2017). Effectiveness of Performance Appraisal System and its Effect on Employee Motivation. Nile Journal of Business and Economics, 5, 15-39.

Mowday, R. T., Porter, L. W., \& Steers, R. (1982). Organizational linkages: The psychology of commitment, absenteeism, and turnover. San Diego, CA: Academic Press. 
International Journal of Business Management and Economic Review

Vol. 5, No. 01; 2022

ISSN: 2581-4664

Neuschel, R. P. (2008). The Servant Leader: Pemimpin Yang Melayani. Jakarta: Akademia.

Northouse, P. G. (2013). Leadership: Theory and Practice (6th ed.). Thousand Oaks: Sage Publications, Inc.

Organ, D. W. (2015). Organizational Citizenship Behavior (Second). Amsterdam: Elsevier Ltd.

Poli, W. I. M. (2019). Kepemimpinan Stratejik: Pelajaran dari Yunani Kuno hingga Bangladesh. Indonesia: Firstbox Media.

Prawirosentono, S. (2010). Manajemen Sumberdaya Manusia: Kebijakan Kinerja Karyawan: Kiat Membangun Organisasi Kompetitif Era Perdagangan Bebas Dudia. Yogyakarta: BPFE.

Purba, E. D., \& Seniati, A. N. L. (2004). Pengaruh kepribadian dan komitmen organisasi terhadap. Makara, Sosial Humaniora, 8(3), 105-111.

Rahayu, S., \& Rozak, H. A. (2021). Pengaruh Kepribadian Dan Pemberdayaan Terhadap Kinerja Melalui Organizational Citizenship Behavior Dengan Modal Sosial Sebagai Variabel Moderating. Prosiding Seminar Nasional Multi Disiplin Ilmu \& Call For Papers Unisbank, 1-19. Semarang: Universitas Stikubank.

Robbins, S. P., \& Judge, T. A. (2017). Essential of Organisational Behaviour (14th ed.). New Jersey: Pearson.

Sinurat, E. M. (2004). Hubungan komitmen organisasi dan pemberdayaan karyawan pada organisasi yang mengalami Downsizing (Studi kasus pada SBN Inaco, PT Sucofindo persero). Jakarta: Perpustakaan Nasional RI.

Titisari, P. (2014). Peranan Organizational Citizenship Behavior (OCB) dalam meningkatkan kinerja karyawan. Jakarta: Mitra Wacana Media.

Wirawan. (2012). Evaluasi Kinerja Sumber Daya Manusia: Teori, Aplikasi, dan Penelitian. Jakarta: Salemba Empat.

Yukl, G. (2010). Leadership in Organizations. In The British Journal of Psychiatry (Seventh Ed, Vol. 112). https://doi.org/10.1192/bjp.112.483.211-a 